\title{
Microorganisms and Detritus in the Water Column of a Subtidal Reef of Natal
}

\author{
M. H. Schleyer \\ Oceanographic Research Institute, P.O. Box 10712, Marine Parade, Durban 4056, South Africa
}

\begin{abstract}
The parameters measured in this study were light and dark-bottle uptake of $\mathrm{NaH}^{14} \mathrm{CO}_{3}$, the chlorophyll content of seawater, direct counts of bacteria, microbial uptake of ${ }^{14} \mathrm{C}$ glucose and a labelled algal extract, organic carbon in the seawater and the composition of debris washed onto the reef. The phytoplankton consisted largely of nannoplankton and primary production was low with an annual mean of $\mathrm{P}=12.82 \mathrm{mg} \mathrm{C} \mathrm{m}^{-3} \mathrm{~h}^{-1}$, while the mean chlorophyll a content of $2.13 \mathrm{mg} \mathrm{m}^{-3}$ was equivalent to a dry biomass of $170.1 \mathrm{mg} \mathrm{m}^{-3}$ Microbial heterotrophic activity was relatively high with an annual mean glucose assimilation of $V_{\max }=0.612 \mu \mathrm{g} \mathrm{l}^{-1} \mathrm{~h}^{-1}$ and a total bacterial count of $2.02 \times 10^{6} \mathrm{ml}^{-1}$, equivalent to a dry biomass of $20.3 \mathrm{mg} \mathrm{m}^{-3}$. The largest proportion of this activity, measured by differential filtration and using antibiotic inhibitors, is performed by free bacteria as opposed to the smaller proportion conducted by bacteria attached to particles, or by microflagellates. Uptake of the labelled algal extract $\left(\mathrm{V}_{\mathrm{max}}=13.2-72.6 \mathrm{mg} \mathrm{C} \mathrm{m}^{-3} \mathrm{~h}^{-1}\right)$ indicates that microbial heterotrophic activity exceeds phytoplankton production. Carbon analyses gave an annual mean of $18.3 \mathrm{~g} \mathrm{~m}^{-3}$ total organic carbon, of which $20 \%$ was particulate, the rest being dissolved organic carbon. Analysis of debris revealed that it consisted almost exclusively of seaweed, except when rivers were in flood, providing a large influx of terrestrial plant debris. These findings are compared with other published results, and their ecological significance is discussed in relation to the remainder of the environment. It is concluded that primary production by phytoplankton is not as important in supporting the biomass of filter feeders on the reef as is heterotrophic activity associated with organic detritus.
\end{abstract}

\section{INTRODUCTION}

The littoral shoreline of Natal (South Africa) is typified by long stretches of surf-washed beaches and sandy substrate interspersed by rocky reefs. Although these reefs are less extensive than the sandy substrate, they are highly productive. Biological studies have been completed on the predominant organisms resident on the reefs at several trophic levels, viz. mussels (Berry, 1978), rock lobsters (Berry, 1971a, b; Smale, 1978; Berry and Smale, 1980), octopus (Smale and Buchan, in prep.) and teleost fish (Berry et al., 1979b; Joubert, 1980; Joubert and Hanekom, 1980). Suspension feeders comprise the dominant faunistic component (Jackson, 1976; Berry et al., 1979a); a study of their particulate detrital and planktonic food sources, crucial to a complete understanding of the reef systems, was lacking until the present work.

Jackson (1976) and Berry (1978) discuss prevalent physical and climatic conditions on the Natal coast that influence the reef habitat; the latter describes the large physical energy subsidies contributed to reef systems by continuous swell and surf action and longshore currents. Large quantities of seaweed and terrestrial macrophyte debris transported by these currents accumulate in the lee of the reefs and are rapidly broken down by turbulence and sand abrasion into fine detrital particles (Berry, 1978; Berry et al., 1979a; Schleyer, 1979, 1980). Berry (1978) suggested that phytoplankton production was too low in Natal waters to support the large populations of suspension-feeders and postulated that they feed on these detrital particles. The purpose of this study was thus to establish the origin and relative abundance of the different particulate fractions available to the suspension-feeders. It forms part of a programme in which the ecology of a shallow subtropical reef community was investigated in terms of energy flow.

\section{MATERIALS AND METHODS}

\section{Study Area}

A small, isolated reef situated in front of the Oceanographic Research Institute (ORI) in Durban, Natal (South Africa), was chosen as study area. This artificial reef, known as ORI Reef (Berry, 1978; Smale, 
1978; Berry et al., 1979a), consists of Table Mountain Sandstone boulders positioned in about 1916 to form the foundation of a pier, which has subsequently been relocated. The boulders have been accreted by oyster shells and the artificial nature of the reef is no longer evident in terms of its external appearance or the biota it supports. It measures approximately $80 \mathrm{~m} \times 20 \mathrm{~m}$ and runs straight out to sea. Only at some spring low tides is a portion of the reef exposed and it can be considered subtidai rather than intertidal. At high tide it is covered by approximately $1 \mathrm{~m}$ to $1.8 \mathrm{~m}$ of water and the top of the reef is usually about $1 \mathrm{~m}$ above the surrounding sand. Occasionally the sides are completely sanded up or undercut to a greater depth by sand scouring. The reef is subjected to continuous surf action; it is densely populated by the mussel Perna perna and inhabited by other suspension-feeders, such as the oyster Crassostrea margaritacea and the tunicate Pyura stolonifera. It is atypical only in its artificial. origin.

\section{Routine Sampling Adjacent to the Reef}

For 1 year, fortnightly samples were collected adjacent to the reef in darkened bottles at a depth of about $1 \mathrm{~m}$. Parameters recorded at the time of sampling included sea temperature, weather and sea conditions. Light intensity was measured at $1 \mathrm{~m}$ depth by means of a luxmeter, this depth being roughly in the middle of the water column, which was constantly mixed by turbulence. Procedures performed on the samples in the laboratory are described below.

\section{Phytoplankton}

Total counts. Total counts of phytoplankton were performed, using the acridine-orange-directcount technique (AODC) devised by Hobbie et al (1977) for counting bacteria. No changes were made to the method except that larger quantities of seawater were filtered through $3.0 \mu \mathrm{m}$ pore size polycarbonate membranes to concentrate the less prolific phytoplankton.

Chlorophylls. Photosynthetic pigments from phytoplankton filtered from water samples were extracted with acetone, measured spectrophotometrically, and their values computed according to Strickland and Parsons (1968). Lenz (1974) multiplies the values obtained for chlorophyll a by a factor of $80 \times$ to obtain dry biomass values, or $40 \times$ to obtain values of phytoplanktonic carbon (see also Strickland, 1975) Only results of chlorophyll a are presented.

Production. Fixation of ${ }^{14} \mathrm{CO}_{2}$ was measured, using the traditional light and dark-bottle method (Vollenweider, 1971) as detailed by Allanson and Hart (1975), except that samples were collected on $0.2 \mu \mathrm{m}$ pore-size polycarbonate membranes (Nuclepore Inc.). These membranes were used in all the tracer work described in this paper and were dissolved with $0.1 \mathrm{ml}$ phenylethylamine before counting in Instagel. This eliminated problems such as chemiluminescence and phosphorescence, which are associated with the use of dioxane, the scintillation cocktail used to dissolve cellulose acetate/nitrate membranes previously employed by certain workers (Ward and Nakanishi, 1971, 1973).

Silver and Davoll (1978) found that loss of fixed ${ }^{14} \mathrm{C}$ a problem caused by addition of a chemical fixative to stop incubation, was reduced if a solution of $I_{2}+K I$ was added instead of formalin. The converse proved true when tested in the ORI Reef experiments, possibly because filtration proceeded soon after incubation was stopped and formalin thus remained the chemical fixative of choice.

At the start of the 6-h incubation period, the samples were placed in an outdoor bath supplied with a constant flow of seawater and screened with plankton and fish net to reduce light intensity to the level recorded in the field at $1 \mathrm{~m}$ depth. Light intensity fluctuated during incubation according to cloud cover and sun elevation, as did the temperature in the water bath according to sea temperature. Computations of production are based on the formulae and tables of Strickland and Parsons (1968).

\section{Bacteria}

Total counts and calculations of bacterial biomass. Total bacterial counts were performed on $0.2 \mu \mathrm{m}$ pore size polycarbonate membranes using the AODC technique already mentioned. The numbers of bacteria attached to detrital particles were recorded, as were the numbers of cocci (including ovoid forms), rods, commas and spirals. Notes were made on the nature. size and abundance of the detrital particles. Scanning electron micrographs provided linear dimensions of the different morphological forms of bacteria, and these were used to calculate mean volumes from which total counts were converted to values of biomass according to Sorokin and Kadota (1972). For this purpose, 10 samples collected over a 5 month period were fixed with glutaraldehyde $(1-2 \%)$, and the bacteria were filtered on $0.2 \mu \mathrm{m}$ pore size polycarbonate membranes. The filters were then dehydrated at half-hour stages in a series of mixtures of ethanol, distilled water and sterile filtered seawater in the following proportions: $1: 1: 8 \rightarrow 2: 1: 7 \rightarrow 3: 1: 6 \rightarrow$ etc. 
$\rightarrow 8: 1: 1 \rightarrow 9: 1: 0 \rightarrow 10: 0: 0$. Subsequently they were critical-point-dried with $\mathrm{CO}_{2}$ and routinely mounted and gold-coated for SEM viewing. The addition of distilled water at the dehydration stages proved necessary to prevent salt crystallisation which obscured the bacteria. The bacteria were well preserved (Fig. 1), but since dehydration followed by critical-point-drying is known to cause specimen shrinkage, the linear dimensions were increased by a factor of $10 \%$. This rather arbitrary figure is based on a study of the problem by Boyde et al. (1977) and is commonly used (Evers, pers. comm.). When observed, microflagellates in these samples were also photographed for measurement.

Assimilation of ${ }^{14} \mathrm{C}$ glucose. Dark assimilation of ${ }^{14} \mathrm{C}$ glucose was measured, using the heterotrophic potential technique of Hobbie and Crawford (1969). A range of 8 concentrations $(0.025$ to $0.2 \mu \mathrm{Ci})$ of $\mathrm{D}-\left[\mathrm{U}-{ }^{14} \mathrm{C}\right.$ ] glucose (specific activity $292 \mathrm{mCi} \mathrm{mmol}^{-1}$ or $1.55 \mathrm{mCi} \mathrm{mg}^{-1}$ ) was added to $25 \mathrm{ml}$ subsamples of seawater, which were incubated for 1 or $2 \mathrm{~h}$ at sea temperature. A modification to the technique involving improved collection of respired ${ }^{14} \mathrm{CO}_{2}$ and advantages in the use of polycarbonate membranes in reducing the filter error are discussed by Schleyer (1980).

$100 \mathrm{ml}$ seawater samples were also incubated with $0.2 \mu \mathrm{Ci}$ labelled glucose and differentially filtered through $3.0 \mu \mathrm{m}$ and $0.2 \mu \mathrm{m}$ pore size polycarbonate membranes after incubation. This procedure was performed during the latter half of the year's sampling to establish whether the fraction of bacteria attached to detrital particles was more active than free bacteria.

\section{Carbon Analysis}

In order to measure dissolved organic carbon (DOC) and particulate organic carbon (POC), unfiltered seawater samples and membrane-filtered samples clear of POC were analysed on a Beckman Carbon Analyser. This gave results of total organic carbon (TOC) and DOC, the difference of which was assumed to comprise POC.

\section{Debris Washed onto the Reef}

'Mats' of debris were observed moving above the sand and accumulating adjacent to the reef in areas of reduced water circulation when sea conditions were calm. Samples of this debris were taken when possible and separated into constituents to establish their origin. These were oven-dried $\left(60^{\circ} \mathrm{C}\right)$ to constant weight and the relative proportions were determined. The calorific content of the constituents of one sample was measured, using an adiabatic bomb calorimeter. For most of the year, conditions were too rough for the mats to form and the debris was churned in the surf and rapidly broken up.

\section{Sampling on a Transect Across the Reef}

Fortnightly samples were taken over a year for total counts of bacteria on a transect across the ORI Reef at stations up-and down-current of the reef and on the reef itself. Samples were taken shortly after the turn to an incoming tide to facilitate collection of the samples and to detect current direction, so that the degree to which the reduced volume of water moving across the reef was filtered by suspension-feeders could be ascertained. Flow of surf onto the reef usually exceeded the flow of longshore currents across it, so that these counts can only be considered an indication of the filtering activity.

\section{Identification of Heterotrophic Microbial Compo- nents and an Assessment of their Importance}

The uptake of a labelled algal extract and of ${ }^{14} \mathrm{C}$ glucose was measured over a 3 month period, using the heterotrophic potential technique in 5 experiments reported by Schleyer (1980). The labelled algal extract consisted of dissolved organics extracted from a ${ }^{14} \mathrm{C}$ labelled Chlorella culture after sonication. It was added to samples at final concentrations of 0.656 to $3.282 \mu \mathrm{g} \mathrm{C} \ell^{-1}$ in an attempt to provide microbial heterotrophs with a tracer similar to the natural substrate and to facilitate measurement of their production. Labelled glucose concentrations were as previously described. Antibiotics were added to duplicate samples to inhibit bacterial activity and assess nonbacterial heterotrophy or uptake of the labelled substrate by passive diffusion. The samples were pre-incubated with antibiotics for an hour in the dark for these to take effect, whereafter nomal incubation of an hour proceeded at sea temperature, again in the dark.

The antibiotics used were gentamycin $\left(20 \mu \mathrm{g} \mathrm{ml}^{-1}\right)$ in 3 of the experiments and a mixture of penicillin $\mathrm{G}(400$ $\mu \mathrm{g} \mathrm{ml} \mathrm{m}^{-1}$ ), streptomycin (200 $\mu \mathrm{g} \mathrm{ml}$ and chloramphenicol $\left(80 \mu \mathrm{g} \mathrm{ml}^{-1}\right)$ in 2 of the experiments. Gentamycin was found by Chróst (1978) to be effective in totally inhibiting bacterial activity after a pre-incubation of an hour at the above concentration, without affecting photosynthetic carbon fixation by freshwater phytoplankton for the next $4 \mathrm{~h}$. It proved ineffective in procuring total bacterial inhibition in this study, but its use is reported since its mode of inhibition was interesting. The other antibiotic mixture described above is recommended for culturing microflagellates axenically (Guillard, 
1973); it proved effective for this purpose with a local species at the above concentrations (Aken, pers. comm.). Nevertheless, it was tested at two and three times these concentrations in a study of its effectiveness and for eukaryotic toxicity in the present work, using differential filtration through $1.0 \mu \mathrm{m}$ and $0.2 \mu \mathrm{m}$ pore size polycarbonate membranes. Other modern antibiotics were tested in synergistic combinations, viz. carbenacillin with gentamycin and with cefoxitin, but were found to be almost as ineffective as gentamycin on its own.

Seawater samples of $100 \mathrm{ml}$ were similarly incubated separately with labelied algal extract and ${ }^{14} \mathrm{C}$

Table 1. Primary production measured using the ${ }^{14} \mathrm{C}$ light and dark bottle method. $(n=29)$

\begin{tabular}{lc|} 
& $\mathrm{mg} \mathrm{C} \mathrm{m} \mathrm{m}^{-3} \mathrm{~h}^{-1}$ \\
\hline Annual mean light-bottle fixation & 12.92 \\
Annual mean dark-bottle fixation & 0.10 \\
Annual mean production & $12.82 \pm 8.51$ \\
Maximum production & 31.29 \\
Minimum production & 1.69 \\
\hline
\end{tabular}

glucose $\left(1.313 \mathrm{mg} \mathrm{Cl}^{-1}\right.$ and $1.290 \mu \mathrm{g} \mathrm{I}^{-1}$ respectively) and differentially filtered through $3.0 \mu \mathrm{m}$ and $0.2 \mu \mathrm{m}$, $2.0 \mu \mathrm{m}$ and $0.2 \mu \mathrm{m}$ or $1.0 \mu \mathrm{m}$ and $0.2 \mu \mathrm{m}$ pore size polycarbonate membranes. These were counted and the percentage uptake of the different size fractions of the nannoplankton was calculated to establish their heterotrophic role.

\section{RESULTS}

\section{Phytoplankton}

The mean temperature of samples collected over the year for these and the following studies was $22.6^{\circ} \mathrm{C}$, with a range from $19.1^{\circ}$ to $26.5^{\circ} \mathrm{C}$.

Primary production was variable and there was a wide range in light and dark-bottle carbon fixation, which had a coefficient of variation of $\pm 66 \%$ around the annual mean of $12.82 \mathrm{mg} \mathrm{C} \mathrm{m}^{-3} \mathrm{~h}^{-1}$ (Table 1). This variability was not clearly related to environmental factors; even though low primary productivity was recorded under turbid and turbulent conditions on most occasions, the two highest measurements were

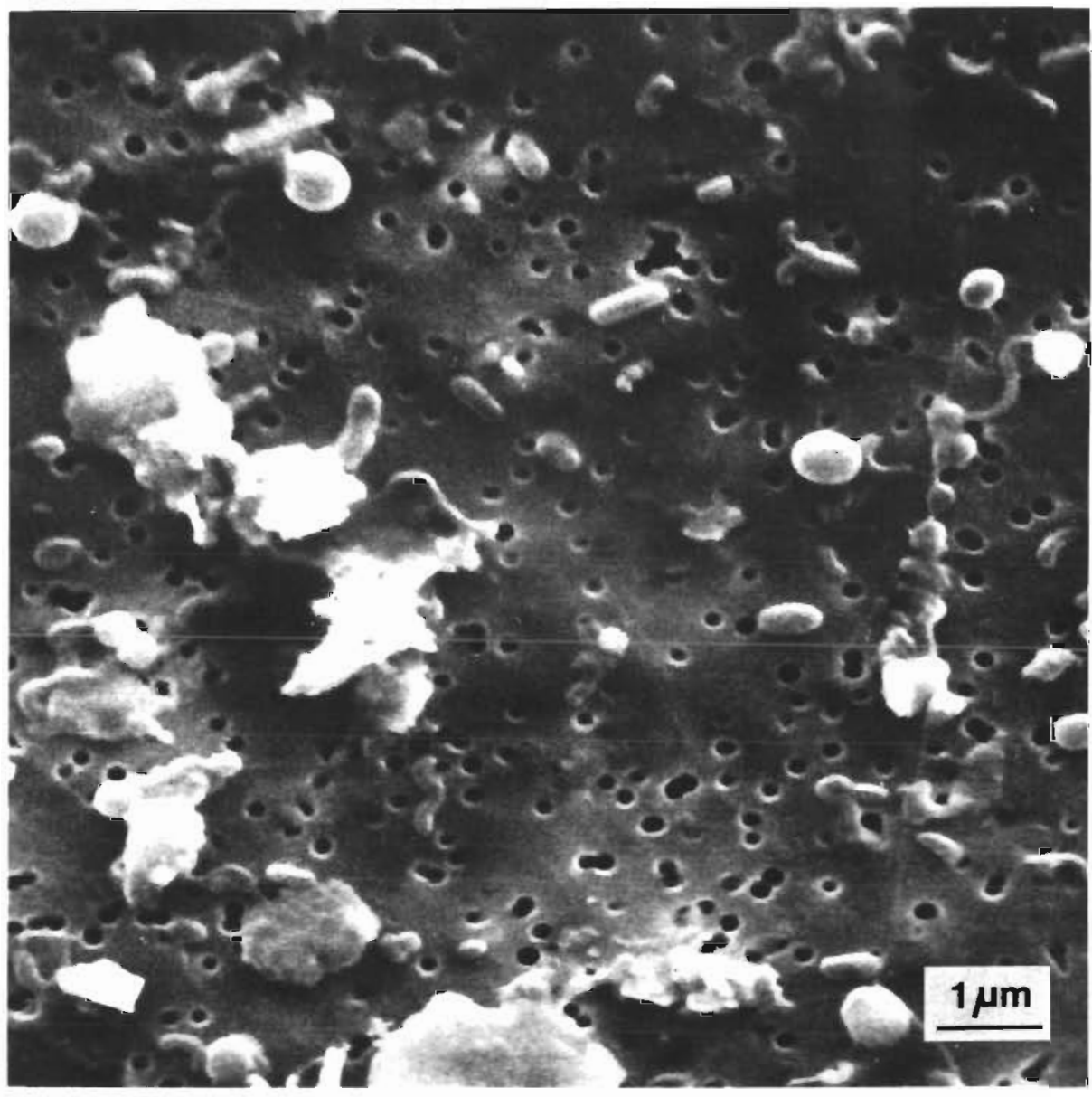

Fig. 1 Scanning electron micrograph of the different morphological types of bacteria with detritus on a $0.2 \mu \mathrm{m}$ pore size polycarbonate membrane filter The bacteria do not appear to have been distorted during preparation for scanning 
taken under these conditions. Chlorophyll a analyses (Table 2) were not as variable, being less dependent on environmental conditions, and the annual mean biomass of phytoplankton was estimated from these analyses to be $170.1 \mathrm{mg} \mathrm{m}^{-3}$ (dry weight).

Using Cassel's (1965) graphical technique, phytoplankton counts were estimated to be precise to only \pm $35 \%$ at a confidence level of $95 \%$ and thus are not presented in detail except as seasonal means (Table 11). These counts fluctuated in general with increase or decrease in the previous parameters and were dominated by microflagellates, referred to as monads by Hobbie et al (1972). Only a few pennate diatoms, filamentous forms and planktonic colonies such as Asterionella japonica were counted.

\section{Bacteria}

The microbes in samples prepared for SEM measurements of bacteria appeared to be well preserved, as there was no evidence of distortion (Figs 1 and 2). The weighted mean diameter of cocci in these samples was $0.476 \mu \mathrm{m}$ (Table 3 ), and some cocci measured were as small as the maximum pore size of the filters used in the study $(0.2 \mu \mathrm{m})$, indicating that a proportion of bacteria was probably lost during filtration. It would have been impossible to measure such small bacteria accurately using light microscopy; hence measurement of the actual bacteria counted by AODC was precluded. This necessitated the separate SEM measurement of bacteria for conversion of total counts to bacterial biomass. A final mean bacterial volume of $0.0516 \mu \mathrm{m}^{3}$ was obtained for this purpose from the measurements, which provided weighted mean volumes of the morphological types of bacteria. These were adjusted to the final volume according to the percentage occurrence of the morphological types in the total counts (Table 3), which did not vary much from sample to sample. The coefficient of variation

Table 2. Phytoplankton biomass determined from analysis of extracted chlorophyll a. $(n=25)$

\begin{tabular}{|lccc|}
\hline & $\begin{array}{c}\mathrm{Chl} \mathrm{a} \\
\left(\mathrm{mg} \mathrm{m}^{-3}\right)\end{array}$ & $\begin{array}{c}\text { Dry biomass } \\
\left(\mathrm{mg} \mathrm{m}^{-3}\right)\end{array}$ & $\begin{array}{c}\text { Phytoplankton } \\
\mathrm{C}\left(\mathrm{mg} \mathrm{m}^{-3}\right)\end{array}$ \\
\hline Annual mean & 2.13 & 170.1 & 85.0 \\
Maximum & 3.88 & 310.4 & 155.2 \\
Minimum & 0.76 & 60.8 & 30.4 \\
\hline
\end{tabular}

Fig. 2. Scanning electron micrograph of a microflagellate with bacteria and small detrital particles on a $0.2 \mu \mathrm{m}$ pore size polycarbonate membrane filter. The microflagellate does not appear to have been distorted during preparation for scanning

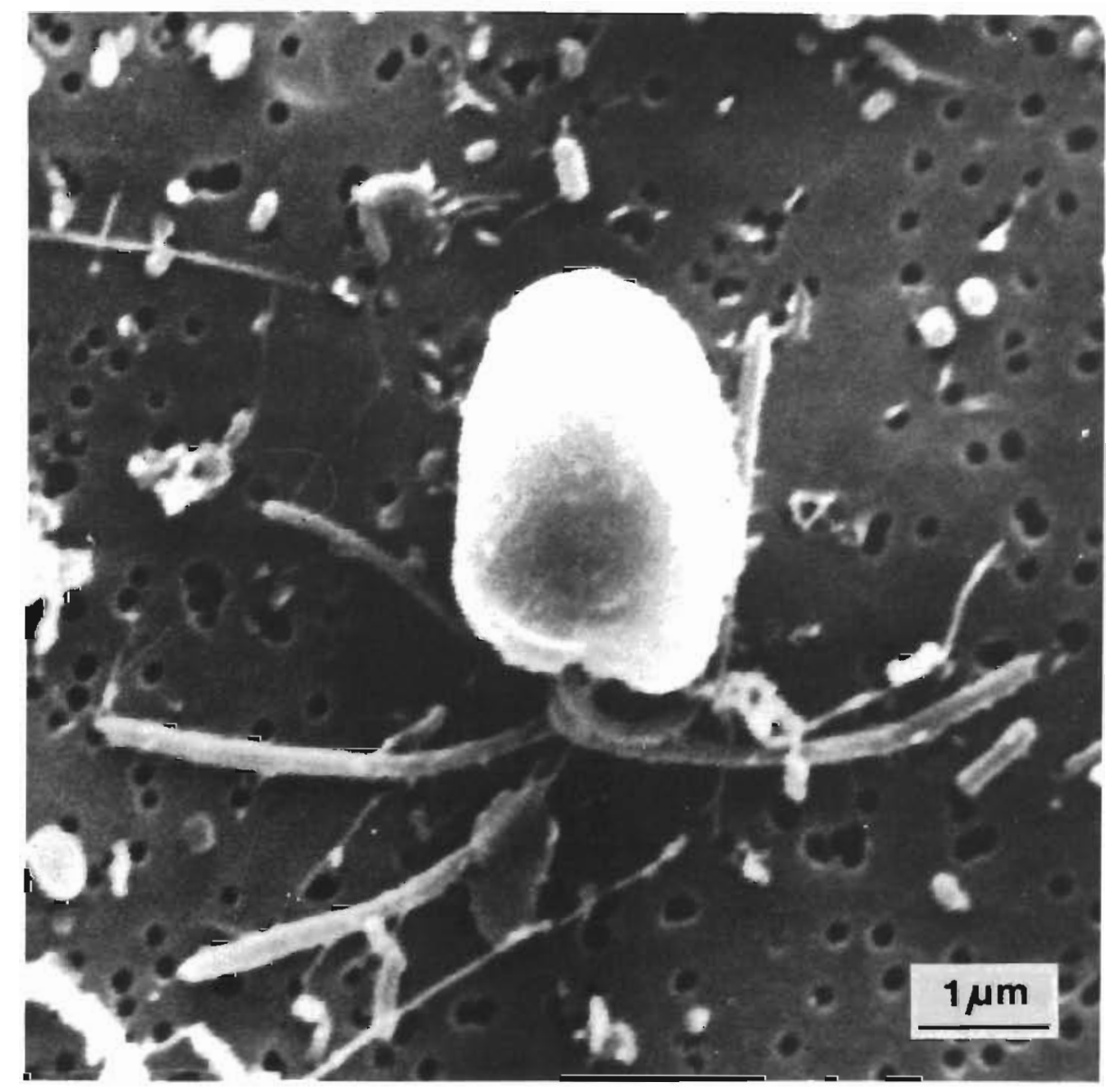


around the weighted mean volumes was fairly low ( \pm $30 \%$ ), suggesting that the final mean volume was acceptable for the intended purpose. Measurement of a small sample $(n=16$ ) of microflagellates provided a mean width for these organisms of $2.32 \mu \mathrm{m}$ (range 1.41 $\mu \mathrm{m}$ to $3.16 \mu \mathrm{m}$ ), this being their smallest dimension.

Using Cassell's (1965) graphical technique, bacterial counts were estimated to be precise to $\pm 11.5 \%$ at a confidence level of $95 \%$, and counts on the reef transect indicated that filtration of these organisms occurred as water moved across the reef. The annual mean differential count across the reef was $0.188 \times 10^{6} \mathrm{ml}^{-1}$ (1.218 $\mathrm{mg} \mathrm{m}^{-3} \mathrm{dry}$ biomass) and on one occasion counts as high as $4.276 \times 10^{6} \mathrm{ml}^{-1}$ occurred, with a differential across the reef of $2.639 \times 10^{6} \mathrm{ml}^{-1}\left(2.723 \mathrm{mg} \mathrm{m}^{-3}\right.$ dry biomass, Table 4).

Counts performed on samples collected for determining the heterotrophic potential were consistent, with an annual mean of $2.02 \pm 0.37 \times 10^{6} \mathrm{ml}^{-1}$ and $a$ mean dry biomass of $20.85 \mathrm{mg} \mathrm{m}^{-3}$ (Table 5). The percentage of bacteria attached to detrital particles was variable, being on average $21 \pm 14 \%$ of the total count. Occasionally this percentage was underestimated when dense detrital particles were present in a sample and bacteria could be counted only on one side of the particles.

The detrital particles were generally amorphous aggregates, rarely including recognisable material derived from living organisms. Most were roughly 5 to $10 \mu \mathrm{m}$ or larger in size, but they could be as small as $1 \mu \mathrm{m}$.

\section{Heterotrophic Activity}

The annual mean of ${ }^{14} \mathrm{C}$ glucose assimilation measured using the heterotrophic potential technique

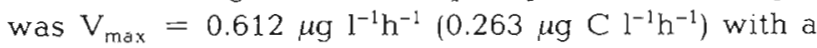
maximum uptake of $2 \cdot 326 \mu \mathrm{g} \mathrm{l}^{-1} \mathrm{~h}^{-1}$ which occurred in spring. These values are listed with other parameters relating to heterotrophic glucose uptake in Table 6 .

In the supplementary experiments in which the uptake of labclled algal extract and labelled glucose were compared, there was no correlation between the uptake of these two substrates (Table 7). An increase or decrease in the uptake of one was generally accornpanied by a similar change in the uptake of the other, but the second highest uptake of the labelled algal extract was accompanied by the second lowest uptake of glucose in the 5 experiments. The previous spring maximum uptake of glucose was exceeded in one of the experiments by a $V_{\max }$ of $2.9 \mu \mathrm{g} \mathrm{l}^{-1} \mathrm{~h}^{-1}(1.247 \mu \mathrm{g}$

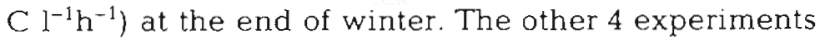
were performed in spring and the mean experimental temperature was $22.0^{\circ} \mathrm{C}$.
Berman (1975) found gentamycin inconsistent in its effectiveness on marine bacteria; it barely reduced microbial activity (by $<30 \%$ ) in 2 of the first 3 of these experiments. The antibiotic mixture (A. M. in Table 7) was far more effective and in most instances reduced

Table 3. Weighted mean bacterial volumes derived from SEM measurements of bacteria from 10 seawater samples. A final mean bacterial volume of $0.0516 \mu^{3}$ used in biomass determinations was calculated according to the percentage density of the different morphological types of bacteria in total counts

\begin{tabular}{|lcccc|}
\hline & $\begin{array}{c}\text { Weight- } \\
\text { ed } \\
\text { mean } \\
\varnothing(\mu \mathrm{m})\end{array}$ & $\begin{array}{c}\text { Weighted mean } \\
\text { volume }\left(\mu \mathrm{m}^{3}\right) \\
\pm \mathrm{s.d}\end{array}$ & $\mathrm{n}$ & $\begin{array}{c}\text { Mean } \% \\
\text { density } \\
\text { in total } \\
\text { counts }\end{array}$ \\
\hline Coccoid forms & 0.476 & $0.0564 \pm 0.0153$ & 808 & 89.5 \\
Rods & - & $0.0146 \pm 0.0028$ & 479 & 3.5 \\
Commas and spirals & - & $0.0096 \pm 0.0029$ & 426 & 7.0 \\
\hline
\end{tabular}

Table 4. Total bacterial counts $\left(\mathrm{x} 10^{6} \mathrm{ml}^{-1}\right)$ along the reef transect. $(n=24)$

\begin{tabular}{|c|c|c|c|}
\hline & Upcurrent & Reef & $\begin{array}{l}\text { Down- } \\
\text { current }\end{array}$ \\
\hline Annual mean & 1.908 & 1.810 & 1.790 \\
\hline $\begin{array}{l}\text { Greatest differential } \\
\text { along transect }\end{array}$ & 4.276 & 2.030 & 1.637 \\
\hline \multicolumn{4}{|c|}{$\begin{array}{l}\text { Mean differential } \\
\text { along transect }=0.118 \times 10^{6} \mathrm{ml}^{-1} \text { (or } 1.218 \mathrm{mg} \mathrm{m}^{-3} \mathrm{dry} \\
\text { biomass) }\end{array}$} \\
\hline
\end{tabular}

Table 5. Total bacterial counts associated with ${ }^{14} \mathrm{C}$ glucose assimilation studies. $(\mathrm{n}=24)$

\begin{tabular}{|llrl|}
\hline & $\begin{array}{c}\text { Counts } \\
\left(\times 10^{6} \mathrm{ml}^{-1}\right)\end{array}$ & $\begin{array}{c}\% \text { Bacteria } \\
\text { attached } \\
\text { to particles }\end{array}$ & $\begin{array}{c}\text { Dry } \\
\text { biomass } \\
\left(\mathrm{mg} \mathrm{m}^{-3}\right)\end{array}$ \\
\hline Annual mean \pm s.d. & $2.020 \pm 0.37$ & 21 & $20.85 \pm 3.81$ \\
Maximum & 2.661 & 59 & 27.46 \\
Minimum & 1.033 & 6 & 10.66 \\
\hline
\end{tabular}

Table 6. Assimilation of ${ }^{14} \mathrm{C}$ glucose measured using the heterotrophic potential technique. Employing the F ratio test, 22 of the 24 experiments proved statistically significant and 16 were predictive as well, the latter being defined as having an $F$ ration greater then 4 times the critical F value. Maximum and minimum values in the table are unrelated, i.e. they are merely the extremes recorded in the separate experiments.

$$
(n=24)
$$

\begin{tabular}{|lccc|}
\hline & $V_{\max }\left(\mu \mathrm{ll}^{-1} \mathrm{~h}^{-1}\right)$ & $\mathrm{T}(\mathrm{h})$ & $\mathrm{K}+\mathrm{S}\left(\mu \mathrm{gl}^{-1}\right)$ \\
\hline Annual mean & 0.612 & 21.4 & 5.23 \\
Maximum values & 2.326 & 210.3 & 17.50 \\
Minimum values & 0.015 & 2.36 & 0.70 \\
\hline
\end{tabular}




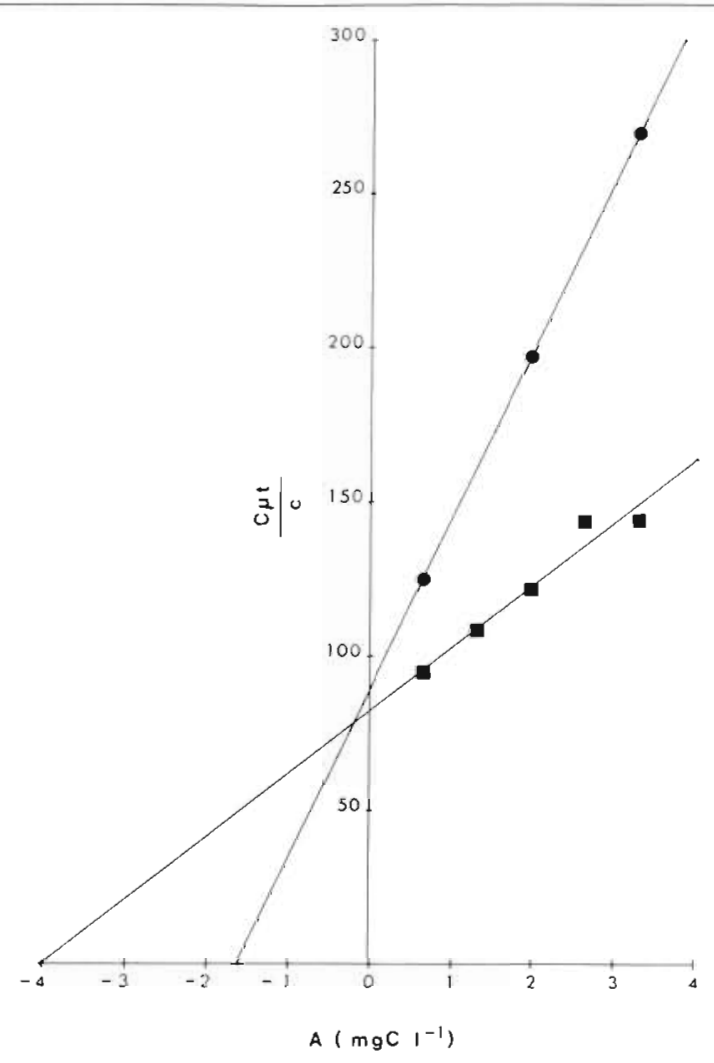

Fig. 3. Typical Lineweaver-Burk plot showing normal uptake of labelled algal extract (squares) and uptake competitively inhibited by gentamycin (circles)

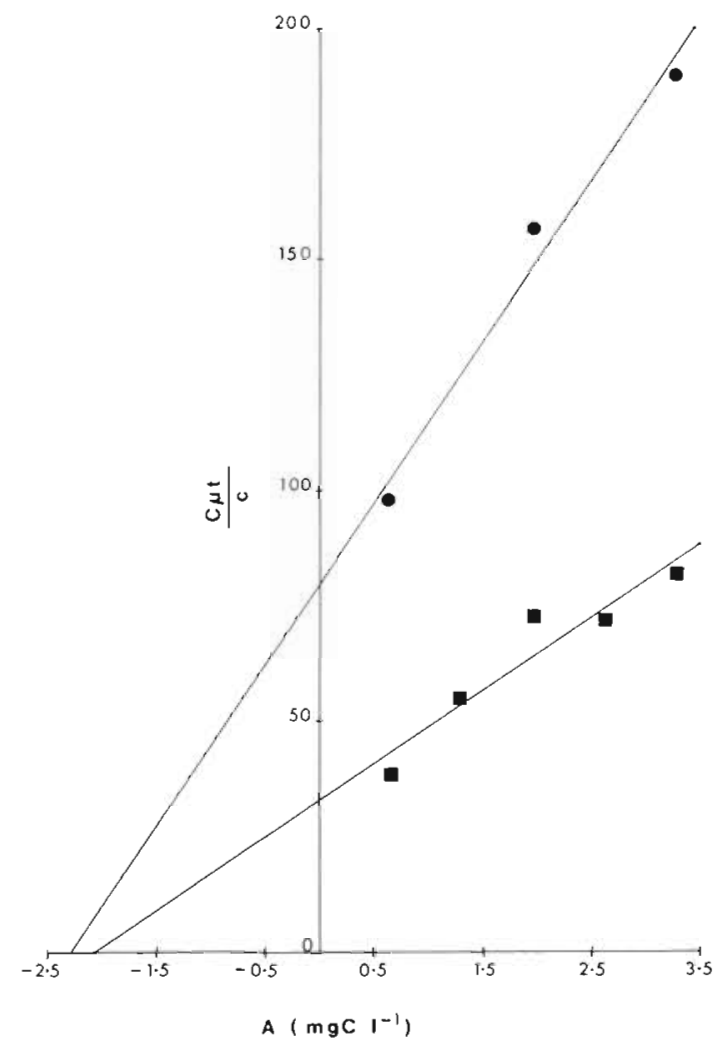

Fig. 4. Typical Lineweaver-Burk plot showing normal uptake of labelled algal extract (squares) and uptake non-competitively inhibited by the antibiotic mixture (circles) microbial activity to below $50 \%$ of normal activity. In action, gentamycin displayed competitive inhibition and the antibiotic mixture non-competitive inhibition (Figs 3 and 4 ); the significance of this is not understood.

The efficacy of the antibiotic mixture was better revealed by the differential filtration experiments designed for this purpose (Table 8), than by the results of the comparative uptake studies which were low and lacked statistical validity. Since the mean diameter of cocci was only $0.476 \mu \mathrm{m}$, most free bacteria would have

Table 7. Results of separate uptake of labelled algal extract and labelled glucose measured in parallel experiments using the helerotrophic potential technique, with and without antibiotics added. All results proved significant at the $95 \%$ level using the F ratio test, except those marked + . Those marked were predictive as well as significant, the former being defined as having an $F$ ratio greater than 4 times the critical $F$ value. The results are partially taken from Schleyer (1980); sample numbers refer to the same samples as those in Tables 8 and 9 . The mean temperature of the experiments was $22^{\circ} \mathrm{C}$

\begin{tabular}{|c|c|c|c|c|c|c|}
\hline \multirow[b]{2}{*}{ Sample } & \multicolumn{3}{|c|}{ Labelled algal extract } & \multicolumn{3}{|c|}{ Labelled glucose } \\
\hline & $\begin{array}{l}V_{\operatorname{mix}} \\
(\mu g C \\
\left.1^{-1} h^{-1}\right)\end{array}$ & $\begin{array}{c}\mathrm{T} \\
(\mathrm{h})\end{array}$ & $\begin{array}{c}K+S \\
\left(\mu g C l^{-1}\right)\end{array}$ & $\begin{array}{c}V_{\max } \\
(\mu g \\
\left.\mathrm{l}^{-1} \mathrm{~h}^{-1}\right)\end{array}$ & $\begin{array}{c}\mathrm{T} \\
\text { (h) }\end{array}$ & $\begin{array}{c}\mathrm{K}+\mathrm{S} \\
\left(\mu \mathrm{g} \mathrm{I}^{-1}\right)\end{array}$ \\
\hline 1 & $32.6^{\circ}$ & $14.5^{\circ}$ & $1049.7^{\circ}$ & 2.9 & 3.2 & 9.2 \\
\hline +gentamycin & $52.1^{\circ}$ & $15.8^{\circ}$ & $820.8^{\circ}$ & $2.4+$ & $3.6+$ & $8.5+$ \\
\hline 2 & $13.2^{\circ}$ & $61.2^{\circ}$ & $807.6^{\circ}$ & 0.1 & 10.6 & 1.3 \\
\hline +gentamycin & 9.8 & 65.8 & 646.2 & $0.1+$ & $12.0+$ & $1.3+$ \\
\hline 3 & $48.9^{\circ}$ & $82.3^{\circ}$ & $4024.7^{\circ}$ & $1.2+$ & $41.8+$ & $48.2+$ \\
\hline +gentamycin & $18.1^{\circ}$ & $88.9^{\circ}$ & $1612.1^{\circ}$ & $0.3+$ & $57.8+$ & $15.2+$ \\
\hline 4 & 63.1 & 32.8 & 2066.6 & $0.6^{\circ}$ & $4.6^{\circ}$ & $2.6^{\circ}$ \\
\hline+ A.M. & $28.7+$ & $79.6+$ & $2283.1+$ & $0.2^{\circ}$ & $13.9^{\circ}$ & $3.0^{\circ}$ \\
\hline 5 & 40.2 & 15.0 & 604.0 & $1.4^{\circ}$ & 4.0 & 5.7 \\
\hline + A.M. & $18.6+$ & $42.4+$ & $787.0+$ & $2.3+$ & $17.9+$ & $40.5+$ \\
\hline
\end{tabular}

Table 8. Effectiveness of the mixture of penicillin G, streptomycin and chloramphenicol in inhibiting bacterial uptake of the labelled algal extract. Concentrations of the antibiotic used were those given in the text or double and treble these concentrations. Samples were differentially filtered through $1.0 \cdot \mu \mathrm{m}$ and $0.2 \mu \mathrm{m}$ pore size polycarbonate membranes; results are presented as percentages of total uptake of the control. Samples numbers refer to the same samples as those in Tables 7 and 9

\begin{tabular}{|c|c|c|c|c|c|}
\hline \multirow[t]{2}{*}{ Sample } & \multirow{2}{*}{$\begin{array}{c}\text { Particle } \\
\text { size }\end{array}$} & \multirow[t]{2}{*}{ Control } & \multicolumn{3}{|c|}{ Antibiotic Concentration } \\
\hline & & & Standard & $\begin{array}{c}\text { Standard } \\
\times 2\end{array}$ & $\begin{array}{c}\text { Standard } \\
\times 3\end{array}$ \\
\hline \multirow[b]{3}{*}{ To } & $>1.0 \mu \mathrm{m}$ & 46.1 & 22.8 & 23.1 & 18.7 \\
\hline & $0.2-1.0 \mu \mathrm{m}$ & 53.9 & 6.9 & 8.4 & 6.4 \\
\hline & tal uptake & 100.0 & 29.7 & 31.5 & 25.1 \\
\hline \multirow[t]{3}{*}{4} & $>1.0 \mu \mathrm{m}$ & 47.8 & 33.0 & & \\
\hline & $0.2-1.0 \mu \mathrm{m}$ & 52.2 & 14.2 & & \\
\hline & tal uptake & 100.0 & 47.2 & & \\
\hline
\end{tabular}


Table 9. Percentage uptake of labelled algal extract and labelled glucose by the different size fractions of the nannoplankton, measured by differential filtration. Results presented as percentages of total uptake; sample numbers refer to the same samples as those in Tables 7 and 8

\begin{tabular}{|c|c|c|c|c|c|c|c|c|}
\hline \multirow[t]{2}{*}{ Sample } & \multicolumn{4}{|c|}{$\begin{array}{c}\% \text { uptake of labelled algal extract } \\
\text { Particle size range }(\mu \mathrm{m})\end{array}$} & \multicolumn{4}{|c|}{$\begin{array}{l}\% \text { uptake of labelled glucose } \\
\text { Particle size range }(\mu \mathrm{m})\end{array}$} \\
\hline & $0.2-1.0$ & $1.0-2.0$ & $2.0-3.0$ & $>3.0$ & $0.2-1.0$ & $1.0-2.0$ & $2.0-3.0$ & $>3.0$ \\
\hline 1 & 74.1 & 12.2 & 4.2 & 9.5 & 86.6 & 9.9 & 1.4 & 2.1 \\
\hline 2 & 40.8 & 22.3 & 5.9 & 31.0 & 76.0 & 14.9 & 0.8 & 8.3 \\
\hline 3 & 53.4 & 21.2 & 5.8 & 19.6 & 86.3 & 8.8 & - & 4.9 \\
\hline 4 & 52.2 & 15.1 & 9.7 & 23.0 & 82.4 & 9.0 & - & 8.6 \\
\hline 5 & 53.8 & 14.3 & 5.6 & 26.3 & 79.3 & 8.8 & 0.3 & 11.6 \\
\hline
\end{tabular}

been in the particulate fraction under $1.0 \mu \mathrm{m}$, which was separated from the fraction containing microflagellates (mean width $2.32 \mu \mathrm{m}$ ) and detrital particles with attached bacteria during differential filtration. Uptake of labelled algal extract by the free bacterial fraction was almost fully depressed by the antibiotic mixture. Uptake by the larger particulate fraction was only partially depressed; since the activity of bacteria attached to detritus was probably also inhibited, this uptake must have been performed mainly by heterotrophic microflagellates. Doubling and trebling the concentration of the mixture did not change the results, and it is assumed that the concentration used in the heterotrophic uptake studies was therefore not toxic to eukaryotes and did not impair their metabolism.

The mean percentage of uninhibited assimilation of labelled glucose by particles $>3.0 \mu \mathrm{m}$ was $11.75 \%$ (range $3.4 \%$ to $38.4 \%$ ), this being established by differential filtration during the routine sampling adjacent to the reef. Once again, this indicates that most of the uptake was performed by particles $<3.0 \mu \mathrm{m}$, predominantly free bacteria, as opposed to the uptake performed by larger particles, including bacteria attached to detritus. Even though they had a mean width of $2.32 \mu \mathrm{m}$, few microflagellates would have been included in the free bacterial fraction, since their other dimensions would have prevented most of them from passing through a $3.0 \mu \mathrm{m}$ pore size filter.

No doubt was left as to the heterotrophic role of the different size fractions of the nannoplankton in the differential filtration study in which samples were filtered through a number of filter sizes after incubation with labelled algal extract and with labelled glucose (Table 9). Free bacteria in the size range $0.2 \mu \mathrm{m}$ to 1.0 $\mu \mathrm{m}$ were the most important, particularly in the case of glucose where they accounted for more than $75 \%$ of the uptake. Particles in the size range $1.0 \mu \mathrm{m}$ to $2.0 \mu \mathrm{m}$ were less important and were identified from SEM measurements as comprising large cocci. The other less active fraction consisted of particles $>3.0 \mu \mathrm{m}$; microflagellates and detritus colonised by bacteria.

\section{Carbon Analysis}

The annual mean values obtained from carbon analyses were: TOC, $18.28 \mathrm{~g} \mathrm{~m}^{-3}$; DOC, $14.75 \mathrm{~g} \mathrm{~m}^{-3}$; by subtraction $P O C, 3.53 \mathrm{~g} \mathrm{~m}^{-3}$.

\section{Analysis of Debris}

The major component of debris samples collected adjacent to the reef during most of the year was seaweed, except after summer rains when rivers came down in flood and washed quantities of terrestrial macrophytes such as reeds into the sea (Table 10).

Table 10. Constituents and their percentage dry weight of debris collected adjacent to the ORI Reef

\begin{tabular}{|c|c|c|c|}
\hline \multirow{3}{*}{$\begin{array}{r}\text { Constituents } \\
\text { Seaweed }\end{array}$} & \multicolumn{3}{|c|}{$\%$ Dry weight } \\
\hline & \multirow{2}{*}{$\begin{array}{c}\text { Mean of } \\
4 \text { samples } \\
73\end{array}$} & \multicolumn{2}{|c|}{$\begin{array}{l}2 \text { samples } \\
\text { after floods }\end{array}$} \\
\hline & & 8 & 9 \\
\hline Terrestrial plant remains & 19 & 86 & 59 \\
\hline Animal remains & 6 & 3 & 24 \\
\hline Miscellaneous & 2 & 3 & 8 \\
\hline
\end{tabular}

\section{Seasonal Means}

Seasonal means (Table 11) were calculated from the annual results by grouping data in seasons determined from monthly means of surf temperatures measured twice daily at Durban from 1957 to 1974 . Most parameters increased slightly or markedly in spring and summer

\section{DISCUSSION}

Uncertainty exists as to the exact nature of the results of ${ }^{14} \mathrm{CO}_{2}$ fixation experiments, whether they provide 
Table 11 Seasonal means of various parameters measured during ORI Reef study

\begin{tabular}{|c|c|c|c|c|}
\hline Season & $\begin{array}{l}\text { Spring } \\
\text { Oct- } \\
\text { Dec }\end{array}$ & $\begin{array}{c}\text { Summer } \\
\text { Jan- } \\
\text { Mar }\end{array}$ & $\begin{array}{c}\text { Autumn } \\
\text { Apr- } \\
\text { Jun }\end{array}$ & $\begin{array}{c}\text { Winter } \\
\text { Jul- } \\
\text { Sep }\end{array}$ \\
\hline \multicolumn{5}{|l|}{ Temperature $\left({ }^{\circ} \mathrm{C}\right)$} \\
\hline Previous records (16 years) & 22.0 & 24.0 & 21.4 & 19.8 \\
\hline ORI Reef samples & 22.4 & 24.4 & 22.4 & 20.2 \\
\hline \multicolumn{5}{|l|}{ Bacteria } \\
\hline Counts $\left(\times 10^{6} \mathrm{ml}^{-1}\right)$ & 2.05 & 2.13 & 1.91 & 1.93 \\
\hline$\%$ attached to particles & 18 & 27 & 20 & 19 \\
\hline Dry biomass (mg m $\mathrm{m}^{-3}$ ) & 21.09 & 22.01 & 19.65 & 19.96 \\
\hline \multicolumn{5}{|l|}{${ }^{14} \mathrm{C}$ glucose assimilation: } \\
\hline$V_{\max }\left(\mu \mathrm{g}^{-1} \mathrm{~h}^{-1}\right)$ & 1.30 & 0.54 & 0.48 & 0.13 \\
\hline $\mathrm{T}(\mathrm{h})$ & 5.4 & 13.7 & 7.6 & 59.1 \\
\hline $\mathrm{K}+\mathrm{S}\left(\mu \mathrm{g} \mathrm{l}^{-1}\right)$ & 7.66 & 4.95 & 2.71 & 3.94 \\
\hline \multicolumn{5}{|l|}{ Phytoplankton } \\
\hline Production ( $\mathrm{mg} \mathrm{C} \mathrm{m} \mathrm{m}^{-3} \mathrm{~h}^{-1}$ ) & 15.92 & 11.45 & 10.73 & 6.23 \\
\hline Counts $\left(\times 10^{3} \mathrm{ml}^{-1}\right)$ & 5.1 & 5.4 & 2.4 & 1.5 \\
\hline Chlorophyll a $\left(\mathrm{mg} \mathrm{m}^{-3}\right)$ & 2.23 & 2.20 & 1.77 & 2.29 \\
\hline Dry biomass ( $\mathrm{mg} \mathrm{m}^{-3}$ ) & 178.4 & 175.8 & 141.7 & 183.5 \\
\hline
\end{tabular}

gross or net values of primary production (Vollenweider, 1971). From progress curves of ${ }^{14} \mathrm{C}$ fixation, Savidge (1978) found that gross uptake occurred during the initial period of incubation. After 2 to $4 \mathrm{~h}$ the ${ }^{14} \mathrm{C}$ had worked its way through the carbon pool, and losses due to respiration and excretion of soluble photosynthetic products caused the measurements to be between gross and net primary production. Peterson (1978) and Farnham and Irvine (1979) also found that net production is overestimated in short incubations using the radiocarbon technique, because respiration losses are not sufficiently taken into account. The quantity of dissolved organics released by phytoplankton under natural conditions is a controversial subject (Riley, 1970; Mann, 1972; Fogg, 1977; Sharp, 1977. 1978; Aaronson, 1978), but Larsson and Hagström (1979) calculated that up to $45 \%$ of phytoplanktonic production is excreted as dissolved organics in the Baltic Sea, and much of this is utilised by bacteria. Lancelot (1979) found that the excretion varies between $0 \%$ and $62 \%$ of the total photo assimilated carbon in the southern North Sea and calculated that up to $39 \%$ of it could be removed by heterotrophs. Thus in the 6-h incubations of the present work, the net primary production will have been overestimated owing to the lag before respiration losses are incurred, and much of the label lost as excreted organics will have been re-assimilated by bacteria, which were also collected on the membranes during filtration.

The mean primary production of $12.82 \mathrm{mg} \mathrm{C} \mathrm{m}^{-3} \mathrm{~h}^{-1}$ (Table 1) measured adjacent to the ORI Reef was comparable to that found at a station near the mouth of Richards Bay at which the conditions were marine
(Hemens et al., 1971), and in Lake Sibaya which was the least productive of tropical freshwater lakes studied at the time (Allanson and Hart, 1975), both these localities being north of Durban in Natal. It was higher than that measured on the continental shelf off Durban by Burchall (1968) who measured a mean surface production of $1.52 \mathrm{mg} \mathrm{C} \mathrm{m}^{-3} \mathrm{~h}^{-1}$ (range 0.01 to 9.52 $\mathrm{mg} \mathrm{C} \mathrm{m} \mathrm{C}^{-3} \mathrm{~h}^{-1}$ ) over a period of 5 years, but considerably lower than that which occurs in areas of upwelling such as the south west Cape coast. For exarmple, daily rates recorded by Henry and Mostert (1977) at a station exposed to the sea in the mouth of Langebaan lagoon indicate approximate primary production of $24 \mathrm{mg} \mathrm{C}$ $\mathrm{m}^{-3} \mathrm{~h}^{-1}$ in winter (April to August), $54 \mathrm{mg} \mathrm{C} \mathrm{m}^{-3} \mathrm{~h}^{-1}$ in spring (September to November) and $66 \mathrm{mg} \mathrm{C} \mathrm{m}^{-3} \mathrm{~h}^{-1}$ in summer (December to February). In adjacent Saldanha Bay an annual mean primary production of 55.7 $\mathrm{mg} \mathrm{C} \mathrm{m} \mathrm{m}^{-1}$ (range 28.0 to $125.7 \mathrm{mg} \mathrm{C} \mathrm{m}^{-3} \mathrm{~h}^{-1}$ ) was estimated from chlorophyll analyses. Thus the primary production measured during this work was relatively low, but it is not possible to specify whether it was close to the gross or net production.

Horne (1969) lists coastal variations in chlorophyll a for different localities with the comment that they are generally variable and high (mostly $>5 \mathrm{mg} \mathrm{m}^{-3}$, range 1 to $91 \mathrm{mg} \mathrm{m}^{-3}$ ). In comparison, the chlorophyll a values measured adjacent to the ORI Reef (Table 2) were low, once again being similar to those found by Allanson and Hart (1975) in the oligotrophic Lake Sibaya $\left(2.6\right.$ to $2.8 \mathrm{mg} \mathrm{m}^{-3}$ ). From the chlorophyll a determinations the annual mean dry biomass of the phytoplankton was estimated to be $170.1 \mathrm{mg} \mathrm{m}^{-3}$, and total counts revealed that this biomass consisted largely, of microflagellates. Primary production in Lake Sibaya was likewise associated with a greater density of microflagellates (Allanson and Hart, 1975), as was the case in the Gulf Stream (Hobbie et al., 1972). This is not surprising in the case of the ORI Reef, where turbulence in the rough surf environment could injure larger phytoplankton.

Benthic seaweeds on the reef form a turf in small patches not colonised by suspension-feeders. They provide an input to the system in that they are closely cropped by fishes (Joubert, 1980; Joubert and Hanekom, 1980), and they appear inconspicuous because of this. Faecal products from these fish enter the detrital food chain, and many species digest only the epiphytic diatoms, the seaweed being excreted in a macerated state. Thus the benthic algal production on the reef was indirectly measured on entry into the water column with detritus imported into the system.

In general the bacteria were small, and most were free-living cocci not attached to particles (Tables 3 and 5). These findings are in agreement with recently published work on aquatic bacteria (Daley and Hobbie, 
1975; Ferguson and Rublee, 1976; Watson et al., 1977; Mazure, 1978). With the exception of Watson et al., total bacterial counts were higher in the present study than in the cited works but with a smaller volume. This is attributable to the technique used, since more small bacteria are filtered and counted on $0.2 \mu \mathrm{m}$ pore size polycarbonate membranes than on the $0.45 \mu \mathrm{m}$ porosity cellulose matrix membranes used by all these authors except Watson et al. The mean diameter of cocci in this study was almost the same as the latter pore size, and many cocci would have been lost in the filtrate or matrix of the filter using cellulosic membranes.

Hoppe (1978) cites $V_{\text {max }}$ values of ${ }^{14} \mathrm{C}$ glucose assimilation expressed in $\mu \mathrm{g} \mathrm{Cl}^{-1} \mathrm{~h}^{-1}$ for coastal and polluted areas as follows: Woods Hole Dock, 0.11; Tokyo Bay, 7.2; Pamlico River Estuary, 1.3 to 3.8 and Shimoda Bay, 9.2. When expressed in the same units, the annual mean and maximum uptake of this substrate by the ORI Reef samples (Tables 6 and 7), $V_{\max }=0.263$ and $1.247 \mu \mathrm{g} \mathrm{C} \mathrm{l}^{-1} \mathrm{~h}^{-1}$ respectively, reveals that microbial activity adjacent to the reef approaches that of polluted areas.

Measurement of the uptake of simple compounds using the heterotrophic potential technique provides a comparative index and not an absolute measure of microbial heterotrophy (Hobbie et al., 1972). However, in evaluating the results of uptake of the labelled algal extract (Table 7), Schleyer, (1980) suggested the values for $V_{\text {nax }}$ were a realistic measure of microbial heterotrophic consumption, provided the labelled extract was representative of the enviromental substrate. If this was the case, heterotrophic production on the reef exceeded the mean primary production by a factor of roughly 4 times. The significance of this is discussed later.

Most of the heterotrophic activity (>50\%) was performed by free bacteria smaller than $1.0 \mu \mathrm{m}$, this being demonstrated by the combination of differential filtration and antibiotic inhibition of bacteria in the uptake experiments (Tables 7 to 9). Similar findings are reported for marine bacteria by Williams (1970), Azam and Hodson (1977) and Cole and Likens (1979) who applied differential filtration techniques in uptake studies, using various labelled substrates in different areas. In the present study, glucose uptake was performed almost exclusively by particles smaller than 3.0 $\mu \mathrm{m}$, as was found by Berman (1975) in the Gulf of California.

This activity of free bacteria is in contrast to the proposal of Wangersky (1977) to the effect that the small size of bacteria means that in the free state they are limited by Brownian movement to a small envelope of water which they impoverish before entering a dormant state, then needing up to six to twelve hours incubation at high nutrient levels for induction to activity. Turbulence on the ORI Reef is likely to preclude such dormancy. Stevenson (1978) further suggested that the prevalent small coccoid bacteria in the aquatic environment are in fact the dormant form. He made this controversial proposal with little supporting physiological evidence, welcoming agreement or disagreement from work it would provoke. Both he and Wangersky felt that dormancy would account for the enigmatic discrepancy between colony counts from plate cultures and total microscopic counts, the latter always greatly exceeding the former. This would appear to involve a contradiction, since if dormancy alone were involved in the discrepancy, on enriched culture the bacteria would re-enter an active state after a lag period, giving a 'full' plate count. As this is not the case, it seems more likely that the aquatic environment has not yet been adequately simulated in culture work.

Recently Kogure et al. (1979) have developed a technique in which direct viable counts of natural bacterial populations closer to total counts ( 10\%) have been made possible by incubation of water samples with nalidixic acid and slight enrichment with yeast extract before performing AODC. This method provided 'a minimum estimate of viable cell numbers' approximately 1000 times greater than plate counts, further highlighting the inadequacy of the latter method.

Switching from dormancy to an active state would not only involve a lag phase but should also include increased respiration as substrate is oxidised for energy in returning to active metabolism. However, uptake of the labelled algal extract proceeded immediately on incubation and was linear over the incubation period, while little of the substrate was respired (Schleyer, 1980). In the same paper, only slight pleomorphic changes are reported as accompanying natural bacterial proliferation in an eight hour study, indicating little change from the predominant dormant' form.

Wangersky (1977) and Stevenson (1978) also contend that bacteria attached to particles are more active, because they live in a micro-environment richer in nutrients than surrounding water by virtue of nutrition intrinsic to particles or adsorbed to them. On a numerical pro rata basis, uptake of labelled substrates by attached bacteria was only slightly lower than uptake by their unattached counterpart in the antibiotic and differential filtration studies. This seems to indicate that attachment to particles did not afford bacteria near-independence from the surrounding water; their nutritional requirements were only slightly better met by the particulate substrate than their free counterparts more dependent on DOC, and they did not appear to 
be more active. None of these results corroborates Wangersky's and Stevenson's theories of dormancy, and it appears that small coccoid bacteria are merely the most efficient morphological form for survival in an environment in which competition for substrates runs high.

The effective, non-competitive nature of the antibiotic mixture used in the inhibition studies (Fig. 4) proved non-toxic to eukaryotes despite the high application concentration. Since free bacteria were almost entirely inhibited, attached bacteria were probably similarly affected, and the heterotrophic uptake by larger particles was probably performed by eukaryotes, predominantly microflagellates (Tables 8 and 9).

Most phytoplankters appear capable of taking up organic substrates by passive diffusion only at concentrations much higher than natural concentrations (Wright and Hobbie, 1966) and the concentrations used in these experiments. However, true heterotrophic organic uptake has been detected in a small number of freshwater phytoplankters (Pollingher and Berman, 1976), and non-pigmented estuarine microflagellates incapable of organic heterotrophy were demonstrated to incorporate labelled organics indirectly by ingestion of bacteria which had assimilated the label (Haas and Webb, 1979). Whatever combination of the latter two mechanisms was involved in heterotrophic uptake by the ORI Reef microflagellates, they accounted on average for $20 \%$ or less of the total uptake of organic substrates.

Seasonal variation in most of the parameters measured was not remarkable (Table 11). The increase in spring and summer of most of the data obtained was probably due to summer storms with their attendant detrital input by rough seas and flooded rivers. However, there was considerable variation in individual measurements that could not be related to the prevailing environmental conditions, since these were so changeable; a level of biological activity procured by a set of environmental conditions would often remain despite a change in the conditions. The greatest seasonal variation was found in the phytoplankton counts, but little accuracy was attributed to these counts (see 'Results').

At this stage, the results can be synthesised with the findings and theories of other workers in a description of the lower levels of the food chain on the ORI Reef. The nutrient source for most of the heterotrophic activity in the ORI Reef water column is undoubtedly seaweed and terrestrial plant debris (Table 10) imported into the system by wave action and currents, these constituting energy subsidies. This is not surprising, since Mann (1972) concluded in a review on the subject that over $90 \%$ of the extensive marine macrophytic production in coastal waters enters the detrital food chain as dissolved or particulate organic matter. The debris on the ORI Reef is rapidly broken down by turbulent surf action and sand abrasion and soluble constituents rapidly leach out of it as it is broken into fine detrital particles. While still organically rich, these are probably heavily colonised by successional pleomorphic stages of bacteria and are rapidly decomposed into relatively inert particles with a reduced microbial flora (Oláh, 1972). As this stage is shortlived, particles as centres of intense metabolic activity are relatively sparse (Azam and Hodson, 1977) and probably insignificant in relation to the activity of the prevalent free bacteria. The remaining inert particles are enriched by the presence of colonising bacteria, which slowly break them down, improving their nutritional value for detritivores rather than the converse (Odum and de la Cruz, 1967; Mann, 1972). It is possible that grazing pressure on these particles by coarse suspension feeders might be the cause of the greater abundance of free bacteria (Sorokin, cited by Azam and Hodson, 1977).

Free bacteria are dependent on DOC as a food source, and carbon analysis revealed that this is more abundant than POC. Although some DOC can be absorbed directly by suspension-feeders (Jørgensen, 1976), it is likely that most of it becomes available to them as particles by way of a complex interaction of biological (bacterial) and physico-chemical processes to which the reviews of Riley (1970) and Mann (1972) provide a good background. The DOC pool appears to consist of two components, the first being an assimilable component to which bacterial activity is related, so that high concentrations of it rarely occur (Andrews and Williams, 1971; Sayler and Gilmour, 1978). In the ORI Reef system this component would be largely derived from leaching of organics from the allochthonous seaweed and plant debris, hence the choice of a labelled algal extract as the substrate in measurements of bacterial activity (Schleyer, 1980). The other component is larger, consisting of accumulated dissolved organics resistant to rapid microbial degradation (Jørgensen, 1976).

In the surf environment, air bubbles are vigorously and constantly introduced into the water. Such bubbles collect surface-active organic material at their gasliquid interface and, on bursting of the bubbles, organic particles form by aggregation (Riley, 1970; Mann, 1972; Wangersky, 1977) in a process which can even include viruses and bacteria known as jet drop enrichment' (Blanchard, 1978). These particles are in equilibrium in a normal distribution with larger particles formed by electrostatic attraction, causing combination of the smaller particles into micelles, the process being irreversible if the micelle components are cemented together by bacteria (Wangersky, 1977). At 
$18{ }^{\circ} \mathrm{C}$ in $0.6 \mathrm{M} \mathrm{NaCl}$, Wangersky cites these micelles as being ellipsoidal and larger than $0.1 \mu \mathrm{m}$. Particles in seawater, including bacteria, always have an electronegative surface charge of varying strength (Neihof and Loeb, 1972), by means of which they may obtain a further organic coating. In this way inorganic particles also become nuclei of organic accretion and by continued bubbling, aggregates up to and over $1 \mathrm{~mm}$ eventually form (Wallace and Duce, 1978). These are probably the common, amorphous particles with few attached bacteria, including little recognisable organic detritus, categorised as flocs and flakes by Wiebe and Pomeroy (1972). They appeared to be the most common type of particle observed in the ORI Reef samples, although they never attained the large size found by Wallace and Duce, probably owing to turbulence. It seems likely that they are derived largely from the unassimilable dissolved organics, since they are so poorly colonised by bacteria.

Paerl $(1974,1978)$ demonstrated that bacteria harvest considerable quantities of DOC and rapidly convert significant amounts of it to particulate (nonrespired) organic carbon, depositing most of it as extracellular material. Since free bacteria exhibited the greatest heterotrophic activity in the ORI Reef experiments, they probably selectively take up assimilable dissolved organics and constitute the most important mechanism by which it is converted into particulate matter. Although microflagellates are apparently also capable of a small amount of such heterotrophic activity, their major contribution is probably in primary production which was low.

The relative abundance and productivity of the photosynthetic and detrital inputs available to suspension-feeders are summarised in Table 12 . It is obvious that, although the bacterial population has a low standing biomass, it has a high turnover rate, evidence for this being the high $V_{\text {max }}$ recorded in the ORI Reef experiments, corroborated by the short generation time ( $<10 \mathrm{~min}$ ) observed for at least one marine bacterial species in culture (Eagon, 1962). Since heterotrophic activity appears to exceed primary production quite considerably, the bacteria should attain a greater biomass than the phytoplankton. This does not occur, and the bacterial population must thus be limited by a combination of availability of food, the assimilable dissolved organics being rapidly consumed by the predominant free bacteria, and by grazing pressure. Bacteria would provide protein-rich food for suspensionfeeders on the ORI Reef if these are adapted to filtering such small filtering particles. If this is not the case, suspension-feeders are limited to filtering out phytoplankton (largely microflagellates) and the less nutritious detrital particles with their attached bacteria. Møhlenberg and Riisgård (1978) found that 9 out of 13 species of suspension-feeding bivalves which they studied were capable of retaining particles down to 1 $\mu \mathrm{m}$ with an efficiency of $-35 \%$ to $70 \%$, and in a similar study 4 species of ascideans retained $1 \mu \mathrm{m}$ particles with an efficiency of $70 \%$ (Randlov and Riisgård, 1979). Thus it is not impossible that the dominant suspension-feeding bivalve on the ORI Reef, Perna perna, which comprises $\sim 70 \%$ of the total biomass (Berry et al., 1979a), is capable of filtering down to the size range of free bacteria. This seems likely, considering the observed reduction in bacterial numbers in water moving across the reef (Table 4 ), which cannot be entirely attributed to patchiness in their distribution, and the filtering ability of $P$. perna is the subject of a study in progress (Schleyer and Berry, in prep.). Whatever the situation, primary production in the water column of the ORI Reef is low, compared with the vast quantities of organic carbon entering the dissolved organic pool and then being consumed by bacteria (Table 12).

Acknowledgements. I gratefully acknowledge financial support for this work by the South African National Comittee for Oceanographic Research and the South African Association for Marine Biological Research. I am also grateful to Dr. P. F. Berry for helpful discussion throughout the duration of this work

Table 12. Relative abundance, productivity and size of photosynthetic and detrital components which become available to suspension feeders on ORI Reef. Calorific values for phytoplankton derived from Platt and Irwin (1972), for local seaweeds from Joubert and Hanekom (1979), for bacteria (cultured Eschenchia coli) from Cummins (1967). The figure for bacterial production is the mean of the $V_{\max }$ values recorded for the uptake of labelled algal extract and includes the small proportion performed by heterotrophic microflagellates (see 'Discussion'). Particle sizes are approximate

\begin{tabular}{lccccc|}
\hline & $\begin{array}{c}\text { Dry biomass } \\
\left(\mathrm{mg} \mathrm{m}^{-3}\right)\end{array}$ & $\begin{array}{c}\text { Organic C } \\
\left(\mathrm{mg} \mathrm{C} \mathrm{m}^{-3}\right)\end{array}$ & $\begin{array}{c}\text { Calorific value } \\
\left(\mathrm{J} \mathrm{g}^{-1}\right)\end{array}$ & $\begin{array}{c}\text { Production } \\
\left(\mathrm{mg} \mathrm{C} \mathrm{m}^{-3} \mathrm{~h}^{-1}\right)\end{array}$ & $\begin{array}{c}\text { Size } \\
\left(\mu \mathrm{m}^{2}\right)\end{array}$ \\
\hline Terrestrial plant debris & - & - & 19,169 & - & - \\
Seaweed & - & - & 19,748 & - & - \\
POC & - & $3.53 \times 10^{3}$ & - & - & - \\
DOC & - & $14.75 \times 10^{3}$ & - & - & - \\
Phytoplankton & 170.10 & 85.00 & 20,616 & 12.82 & $\leq 2$ \\
Bacteria & 20.85 & 10.43 & 23,074 & 47.60 & $\leq 1$ \\
\hline
\end{tabular}




\section{LITERATURE CITED}

Aaronson, S. (1978). Excretion of organic matter by phytoplankton in vitro. Limnol. Oceanogr. 23: 838

Allanson, B. R., Hart, R, C. (1975). The primary production of Lake Sibaya, KwaZulu, South Africa. Verh. Internat. Verein. Lımnol. 19: 1426-1433

Andrews, P., Williams, P. J. Le B. (1971). Heterotrophic utilization of dissolved organic compounds in the sea. III Measurement of the oxidation rates and concentration of glucose and amino acıds in sea water J. mar. biol. Ass. U.K. $51 \quad 111-125$

Azam, F., Hodson, R. E. (1977). Dissolved ATP in the sea and its utilization by marine bacteria. Nature, Lond. 267 696-697

Berman, T (1975). Size fractionation of natural aquatic populations associated with autotrophic and heterotrophic carbon uptake. Mar. Biol. 33: 215-220

Berry, P. F. (1971a). The spiny lobsters (Palinuridae) of the east coast of southern Africa: Distribution and ecological notes. Invest. Rep. oceanogr. Res. Inst., Durban 27: 1-23

Berry, P. F. (1971b). The biology of the spiny lobster Panulirus homarus (Linnaeus) off the east coast of southern Africa Invest. Rep. oceanogr Res. Inst., Durban 28: 1-75

Berry, P. F. (1978). Reproduction, growth and production in the mussel, Perna perna (Linnaeus), on the east coast of South Africa. Invest. Rep. oceanogr. Res. Inst., Durban 48: $1-28$

Berry, P. F., Hanekom, P., Joubert, C., Joubert, I., Schleyer M., van der Elst, R. (1979a). Preliminary account of the biomass and major energy pathways through a Natal nearshore reef community. S. Afr. J. Sci. 75: 565

Berry, P. F., Smale, M. J., Hanekom, P., Joubert, C., Joubert, I., van der Elst, R. (1979b). Density and biomass of teleosts on the ORI Reef, Natal. S. Afr. J. Sci. 75: 566

Berry, P. F., Smale, M. J. (1980). An estimate of production and consumption rates in the spiny lobster Panulirus homarus on a shallow littoral reef off the Natal Coast, South Africa. Mar Ecol. Prog. Ser. 2: 337-343

Blanchard, D. C. (1978). Jet drop enrichment of bacteria, virus and dissolved organic material. Pure Appl. Geophys. 116: 302-308

Boyde, A. E., Bailey, E., Jones, S. J., Tamarin, A. (1977). Dimensional changes during specimen preparation for scanning electron microscopy. In: Johari, $O$. (ed) Scanning electron microscopy: proceedings of the scanning electron microscope symposium, Vol. 1 Illinois Institute of Technology and Research Institute, Chicago, Illinois

Burchall, J. (1968). An evaluation of primary productivity studies - the Continental Shelf region of the Agulhas Current near Durban (1961-1966). Invest. Rep. oceanogr. Res. Inst., Durban 21: 1-44

Cassell, E. A. (1965). Rapid graphical method for estimating the precision of direct microscopic counting data. Appl. Microbiol. 13: 293-296

Chróst, R. J. (1978). The estimation of extracellular release by phytoplankton and heterotrophic activity of aquatic bacteria. Acta microbiol. pol. 27: 139-146

Cole, J. J., Likens, G. E. (1979). Measurements of mineralization of phytoplankton detritus in an oligotrophic lake. Limnol. Oceanogr. 24:541-547

Crawford, C. C., Hobbie, J. E., Webb, K. L. (1974). The utilization of dissolved free amino acids by estuarine microorganisms. Ecology 55: 551-563

Cummins, K. W (1967). Calorific equivalents for studies in ecological energetics. University of Pittsburgh, Pittsburgh.
1967: $1-52$

Daley, R. J., Hobbie, J. E. (1975). Direct counts of aquatic bacteria by a modified epifluorescence technique. Limnol Oceanogr. 20: 875-882

Eagon, R. G. (1962). Pseudomonas natriegens, a marine bacterium with a generation time of less than 10 minutes. J. Bact. 83: 736-737

Farnham, W. F., Irvine, L. M. (1979). What does 14 C-uptake by phytoplankton really measure? A fresh approach using a theoretical model. Br. Phycol. J. 14: 122-123

Ferguson, R. L., Rublee, P. (1976). Contribution of bacteria to standing crop of coastal plankton. Limnol. Oceanogr. 21: 141-149

Fogg, G. E. (1977). Excretion of organic matter by phytoplankton. Limnol. Oceanogr. 22: 576-577

Guillard, R. R. L. (1973). Methods for microflagellates and nannoplankton. In: Stein, J. R. (ed.) Handbook of phycological methods. Cambridge University Press, Cambridge, pp. 69-85

Haas, L. W., Webb, K. L. (1979). Nutritional mode of several nonpigmented microflagellates from the York River estuary, Virginia. J. exp. mar. Biol. Ecol. 39: 125-134

Hemens, J., McClurg, T P., Simpson, D. F., Warwick, R. J. (1971). Detailed survey of Richards Bay. Progress report, CSIR/NIWR 22nd steering committee meeting: Marine disposal of effluents. Council for Scientific and Industrial Research, Petroria, South Africa 21: 1-13

Henry, J. L., Mostert, S. A., Christie, N. D. (1977). Phytoplankton production in Langebaan Lagoon of Saldanha Bay. Trans. R. Soc. S. Afr. 42: 383-398

Hobbie, J. E., Crawford, C. C. (1969). Respiration corrections for bacterial uptake of dissolved organic compounds in natural waters. Limnol. Oceanogr 14:528-532

Hobbie, J. E., Daley, R. J., Jasper, S. (1977). Use of nuclepore filters for counting bacteria by fluorescence microscopy. Appl, envir. Microbiol. 33: 1225-1228

Hobbie, J. E., Holm-Hansen, O., Packard, T., Pomeroy, L. R., Sheldon, R. W., Thomas, J. P., Wiebe, W. J. (1972). A study of the distribution and activity of microorganisms in ocean water. Limnol. Oceanogr. 17: 544-555

Hoppe, H. G. (1978). Relations between active bacteria and heterotrophic potential in the sea. Neth. J. Sea Res. 12: 78-98

Horne, R. A. (1969). Marine chemistry: the structure of waters and the chemistry of the hydrosphere, Wiley-Interscience, London

Jackson, L. F. (1976). Aspects of the intertidal ecology of the east coast of South Africa. Invest. Rep. oceanogr. Res. Inst., Durban 46: 1-72

Jørgensen, C. B. (1976). August Pütter, August Krogh, and modern ideas on the use of dissolved organic matter in aquatic environments. Biol. Rev. 51: 291-328

Joubert, C. S. W., Hanekom, P. B. (1980). A study of feeding in some inshore reef fish of the Natal coast, South Africa. S.A. J. Zool 15: 262-274

Joubert, I. (1980). The biology of Blennius cristatus L. and Blennius cornutus L. (Teleostei - Blennioidea) on a Natal reef: Thesis submitted ... for the degree of Master of Science, University of Natal, Durban

Kogure, K., Simidu, U., Taga, N. (1979). A tentative direct microscopic method for counting living marine bacteria. Can. J. Microbiol. 25: 415-420

Lancelot, C. (1979). Gross excretion rates of natural marine phytoplankton and heterotrophic uptake of excreted products in the Southern North Sea, as determined by shortterm kinetics. Mar. Ecol. Prog. Ser. 1: 179-186

Larsson, U., Hagström, A. (1979). Phytoplankton exudate 
release as an energy source for the growth of pelagic bacteria. Mar Biol. 52: 199-206

Lenz, J. (1974). On the amount and size distribution of suspended organic matter in the Kiel Bight. Ber. dt. wiss. Kommn. Meeresforsch. 23: 200-225

Mann, K. H. (1972). Macrophyte production and detritus food chains in coastal waters. Mem. Ist. ital. Idrobiol. 29 (Suppl.): $353-383$

Mazure, H. G. F. (1978). The seasonal cycle of marine bacteria in a west coast kelp-bed. Trans. R. Soc. S. Afr. 43: 119-124

Møhlenberg, F., Riisgård, H. U. (1978). Efficiency of particle retention in 13 species of suspension leeding bivalves. Ophelia 17: $239-246$

Neihof, R. A., Loeb, G. I. (1972). The surface charge of particulate matter in seawater. Limnol. Oceanogr. 17: 7-16

Odum, E. P., de la Cruz, A. A. (1967). Particulate organic detritus in a Georgia salt marsh-estuarine ecosystem. In: Lauff, G. H. (ed.) Estuaries. American Association for the Advancement of Science 83: 383-388

Oláh, J. (1972). Leaching, colonization and stabilization during detritus formation. Mem. Ist. ital. Idrobiol. 29 (Suppl.): $105-127$

Paerl, H. W (1974). Bacterial uptake of dissolved organic matter in relation to detrital aggregation in marine and freshwater systems. Limnol. Oceanogr. 19: 966-972

Paerl, H. W (1978). Microbial organic carbon recovery in aquatic ecosystems. Limnol. Oceanogr 23: 927-935

Peterson, B. J. (1978). Radiocarbon uptake: its relation to net particulate carbon production. Limnol. Oceanogr. 23: $179-184$

Platt, T., Irwin, B. (1973). Caloric content of phytoplankton. Limnol. Oceanogr. 18: 306-310

Pollingher, U., Berman, T (1976). Autoradiographic screening for potential heterotrophs in natural algal populations of Lake Kinneret. Microbial ecology 2: 252-260

Randlov, A., Riisgård, H. U. (1979). Efficiency of particle retention and filtration rate in four species of ascidians Mar. Ecol. Prog. Ser. 1: 55-59

Riley. G. A. (1970). Particulate organic matter in sea water. Adv. mar. Biol. 8: 1-1.18

Savidge, G. (1978). Variations in the progress of $14 \mathrm{C}$ uptake as a source of error in estimates of primary production. Mar. Biol 49: 295-301

Sayler, G. S., Gilmour, C. M. (1978). Heterotrophic utilization of organic carbon in aquatic environments. J. envir. Qual. 7: $385-391$

Schleyer, M. H. (1979). Preliminary results of a comparative study of the roles of bacteria and phytoplankton in the littoral waters of Natal. S. Afr. J. Sci. 75: 566

Schleyer, M. H. (1980). A preliminary evaluation of heterotrophic utilisation of a labelled algal extract in a subtidal reef environment. Mar Ecol. Prog. Ser 3: 223-229

Schleyer, M. H., Berry, P. F. (in prep.), Filtration rate, assimilation efficiency and particle retention of the brown mussel, Perna perna (L.).

Sharp. J H. (1977). Excretion of organic matter by marine phytoplankton: do healthy cells do $\mathrm{xt}$ ? Limnol. Oceanogr 22: 381

Sharp, J. H. (1978). Reply to comment by S. Aaronson. Limnol. Oceanogr 23: 839-840

Silver, M. W., Davoll, P. J. (1978). Loss of 14 C activity after chemical fixation of phytoplankton: error source for autoradiography and other productivity measurements. Limnol. Oceanogr. 23: 362-368

Smale, M. J (1978). Migration, growth and feeding in the Natal rock lobster Panulirus homarus (Linnaeus). Invest. Rep. oceanogr. Res. Inst., Durban 47: 1-56

Smale, M. J., Buchan, P. R. (in prep.). The biology of Octopus vulgaris Cuvier off the east coast of South Africa

Sorokin, Y I, Kadota, H. (eds) (1972). Techniques for the assessment of microbial production and decomposition in fresh waters. Blackwell Scientific Publications, Oxford, pp. $48-50$

Stevenson, M. L. (1978). A case for bacterial dormancy in aquatic systems. Microbial ecology 4: 127-133

Strickland, J. D. H., Parsons, T R. (1968). A practical handbook of seawater analysis. Bull. Fish. Res. Bd Can. 167: $1-311$

Vollenweider, R. A. (1969). A manual on methods for measuring primary production in aquatic environments, Blackwell Scientific Publications, Oxford

Wallace, G. T., Duce, R. A. (1978). Transport of particulate organic matter by bubbles in marine waters. Limnol. Oceanogr. 23: 1.155-1167

Wangersky, P. J. (1977). The role of particulate matter in the productivity of surface waters. Helgolander wiss. Meeresunters. 30: 546-564

Ward, F. J., Nakanishi, M. (1971). A comparison of GeigerMeuller and liquid scintillation counting methods in estimating primary productivity. Limnol. Oceanogr. 16: 560-563

Ward, F. J., Nakanishi, M. (1973). A comparison of liquid scintillation and Geiger-Müller estimates of primary productivity in an in situ experiment. J. Fish. Res. Bd Can. 30: $708-711$

Watson, S. W., Novitsky, T J., Quinby, H. L., Valois, F. W (1977). Determination of bacterial number and biomass in the marine environment. Appl. envir Microbiol. 33: 940-946

Wiebe, J., Pomeroy, L. R. (1972). Microorganisms and their association with aggregates and detritus in the sea: a microscopic study. Mem. Ist. ital. Idrobiol. 29 (Suppl.): 325-352

Williams, P. J. Le B. (1970). Heterotrophic utilization of dissolved compounds in the sea. I. Size distribution of population and relationship between respiration and incorporation of growth substrates. J. mar. biol. Ass. U.K. 50: 859-870

Wright, R. T., Hobbie, J. E. (1966). Use of glucose and acetate by bacteria and algae in aquatic ecosystems. Ecology 47 : $447-464$ 